\title{
Seven Little-Known Birds of the Inner Ear
}

I.

The breath of the cedar waxwing whistling in the juniper must smell like gin. No one will ever know. One pitch higher is the sound of gin evaporating.

II.

It is no mystery we never see yellow birds in the evening

III.

when the black ones come in flocks.

IV.

The American bittern hiding in our tomatoes cranes his beak skyward between the stakes and sways like a reed. No wind.

v.

A chicken with its back to us frightens and angers us at the same time. I showed a toy rooster to my infant girl, his ugly beak and comb hanging over her crib, and she screamed. How do we know the face of death? When he comes crowing.

VI.

The stirrup, anvil, and hammer can be welded into the shape of the sound of a merlin perched, divining the future over entrails, divining the sparrow.

VII.

Andrea, my dead friend, used to say, Hide $\&$ watch, meaning, You'll see. And now she does. School children sent a thousand paper cranes from Kyoto, and no one has told them what became of her.

Did I say divining? I meant dividing. If this must take a shape, let it be a lofty thousand sand hill cranes we hear but never see. If I say I need a drink, what I mean is I need the breath of the cedar waxwing. 